$$
-
$$



Cultural Memory

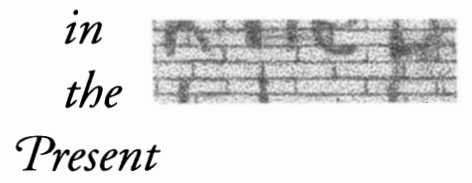

Mieke Bal and Hent de Vries, Editors 



\section{THE POLITICS OF AESTHETICS}

Nationalism, Gender, Romanticism

Marc Redfield

STANFORD UNIVERSITY PRESS

STANFORD, CALIFORNIA 
Stanford University Press

Stanford, California

(C) 2003 by the Board of Trustees of the

Leland Stanford Junior University. All rights reserved.

"b o d y" from A Scattering of Salts by James Merrill, copyright (C) 1995 by James

Merrill. Used by permission of Alfred A. Knopf, a division of Random House, Inc.

Library of Congress Cataloging-in-Publication Data

Redfield, Marc.

The politics of aesthetics : nationalism, gender, romanticism / Marc Redfield.

p. cm.- (Cultural memory in the present)

Includes bibliographical references and index.

ISBN: 978-0-8047-4460-7

ISBN: 978-0-8047-4750-9

I. Aesthetics-Political aspects. 2. Romanticism-Political aspects.

I. Title. II. Series.

BH3OI.P64 R43 2003

III'. 85 - dc2I

2002015100

\section{Original Printing 2003}

Last figure below indicates year of this printing:

$\begin{array}{llllllll}\text { I2 } & \text { II } & \text { IO } & 09 & 08 & 07 & 06 & 05\end{array}$

Typeset by Alan Noyes in II/13.5 Adobe Garamond. 
For Molly

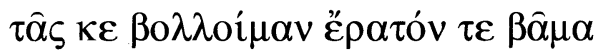

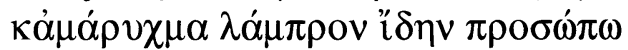

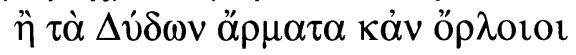

$\pi \varepsilon \sigma \delta \circ \mu \alpha \dot{\chi} \chi \varepsilon v \tau \alpha \varsigma$ 
